\title{
GEOLOGY
}

DOI https://doi.org/10.30525/978-9934-26-047-6-48

\section{ПРО ВЗАСМОУЗГОДЖЕНІСТЬ ФОРМУВАННЯ МЕТАМОРФОГЕННИХ ТА ГРАНІТОЇДНИХ КОМПЛЕКСІВ СОРОКИНСЬКОЇ ЗОНИ (ПРИАЗОВСЬКИЙ МЕГАБЛОК УКРАЇНСЬКОГО ЩИТА)}

\author{
Осьмачко Л. С. \\ кандидат геологічних наук, старший науковий співробітник \\ ДУ «Інститут геохімії навколишнього середовища \\ Національної академії наук України» \\ м. Київ, Україна
}

Сорокинська зона розломів ускладнюе Західноприазовську антиклінорну зону [1] Приазовського мегаблоку Українського щита (УЩ) й простягається на північний захід майже на 50 км при ширині 2-2,5 км. Відклади осипенківської серії, що виповнюють зону, формують синклінальну складку з крутим падінням крил на південний захід $[2,3]$. Нижню вікову межу порід серії визначає U-Pb ізохронна дата 3330 млн р., верхню - 2802 млн р. $[2,4]$. Попри численні доробки попередніх дослідників [1-6 та ін.], залишаються відкритими питання щодо умов формування рудоперспективних об'єктів даної частини УЩ. Проведені додаткові дослідження Сорокинської зони в басейні p. Берди [7]. Встановлено, що речовинно різні геологічна тіла-складові Сорокинської зони сформовані схожими структурно-речовинними парагенезисами (рис. 1-3). Схожі вони за просторовим положенням, кількістю генерацій структурних елементів, Р-Т умовами реалізації. Отже, всі досліджувані породні різновиди Сорокинської зони формувалися подібно й поступово, структурно-речовинні трансформації в їх об’ємах відбувалися кооперативно/одночасно, в декілька етапів у суттєво здвигових тектонічних умовах на фоні регресивної зміни Р-Т параметрів середовища. Такі перетворення проходили сумісно в усьому об'ємі фрагменту фундаменту, що досліджувався - від мікро- до макрорівня його петро-структурної організації. Про останне свідчить самоподібність структурних форм на всіх рівнях супідрядності. Тобто, досліджуваний об'єм кристалічних порід, разом 3 гломерою рідкісноземельних пегматитів Балка Крута, є єдиною дислокаційною системою, яка формувалася щонайменше за п'ять етапів структурних i 
речовинних перетворень кристалічної основи в Р-Т умовах від гранулітової до зеленосланцевої фацій метаморфізму.

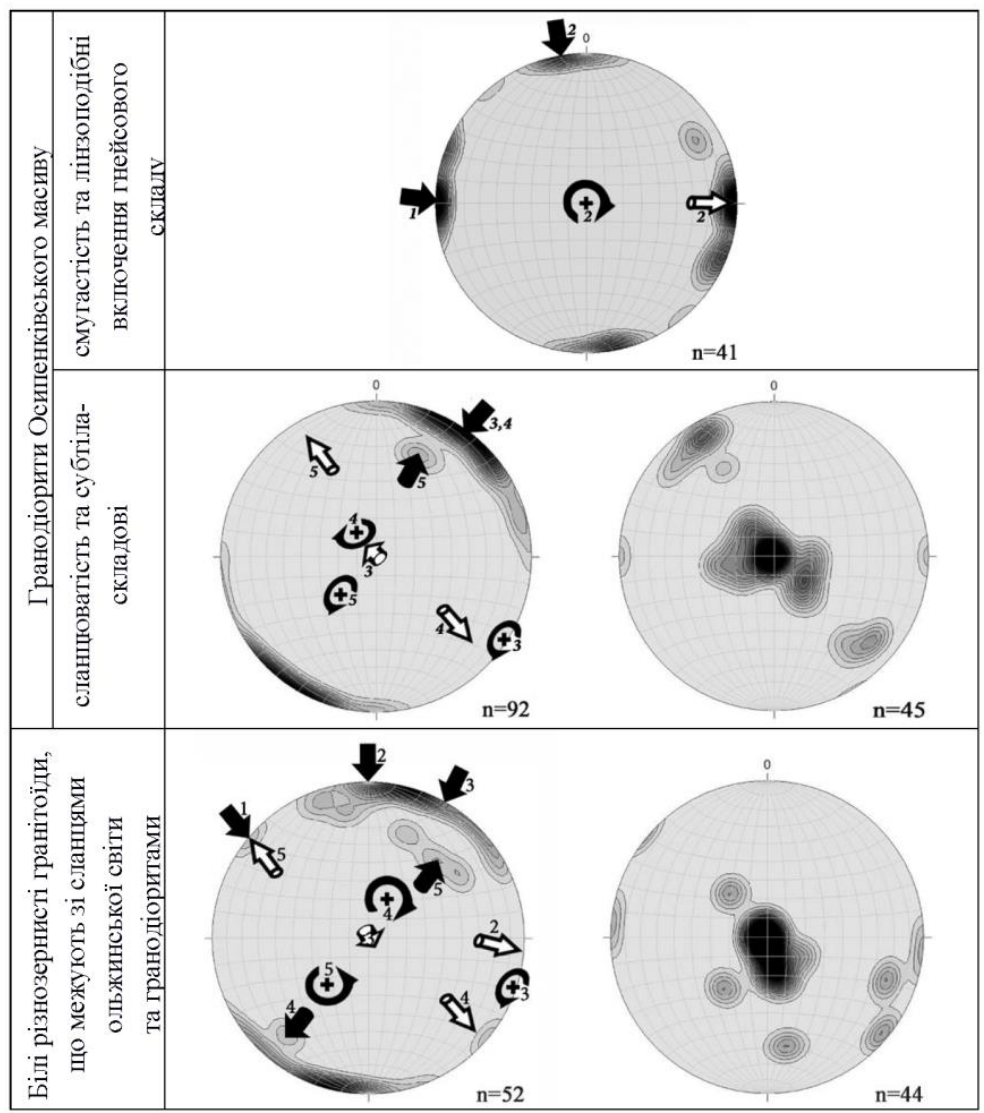

a

б

Рис. 1. Стереограми полюсів площин смугастості, сланцюватості

і тіл-складових (а) й занурення мінеральної лінійності

(б) для гранітоїдів, що межують 3 гнейсово-сланцевими товщами Сорокинської зони

Нижня півсфера. Ізолінії: 1-3-5-7-9-11-13-15. Стрілки - напрямки дії тектонічних тисків: чорні прямі - стиснення (для спрощення показано однією стрілкою), білі - розтягу; округлі - ротаиії та їх вісь (хрестик). Цифри поручіндекс етапу. $n$ - кількість замірів. 


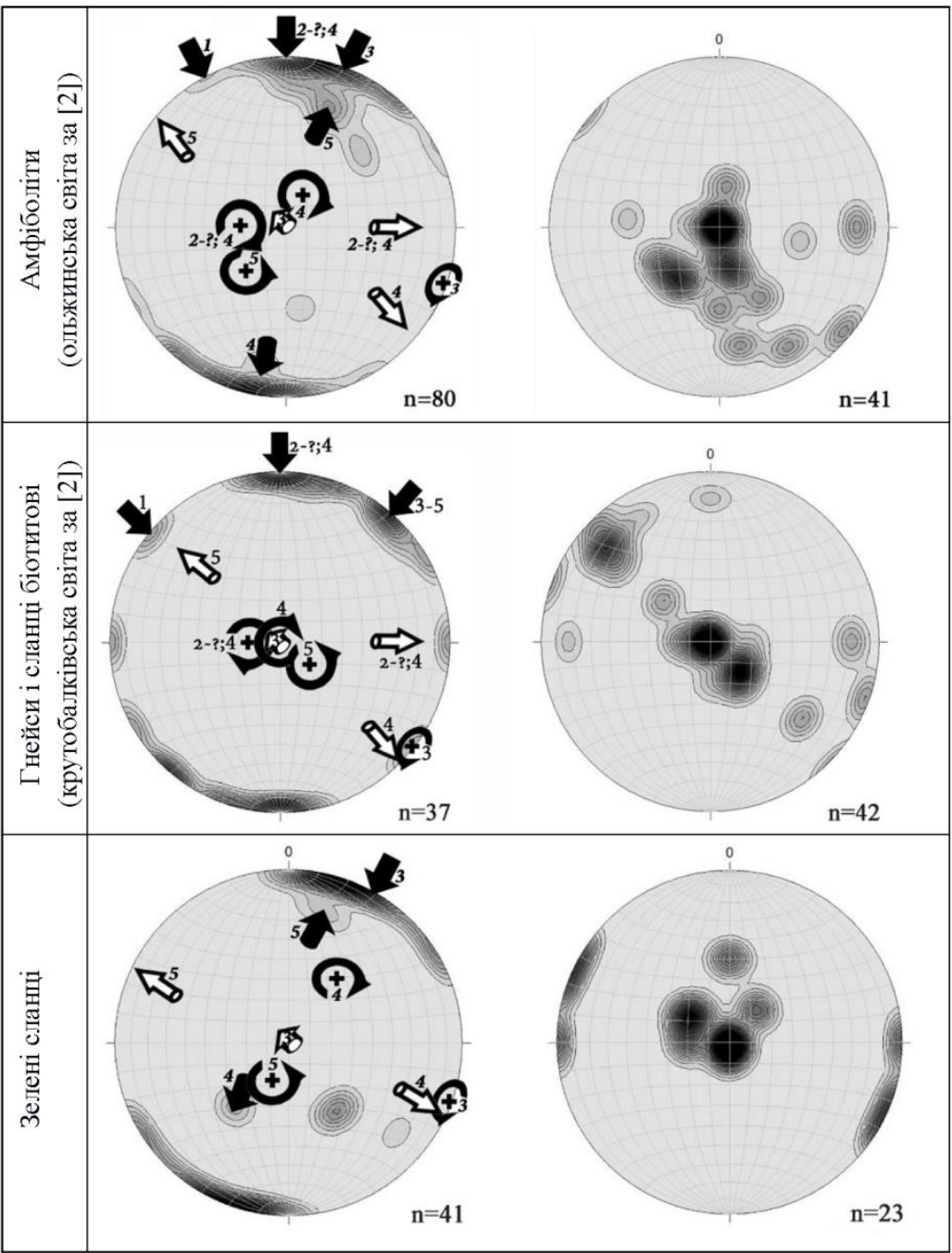

a

б

Рис. 2. Стереограми полюсів площин смугастості

і сланцюватості (а) та занурення лінійності за мінеральними агрегатами й осями складчастих форм (б) для гнейсово-сланцевих товщ Сорокинської зони

Інші позначення див. рис. 1. 


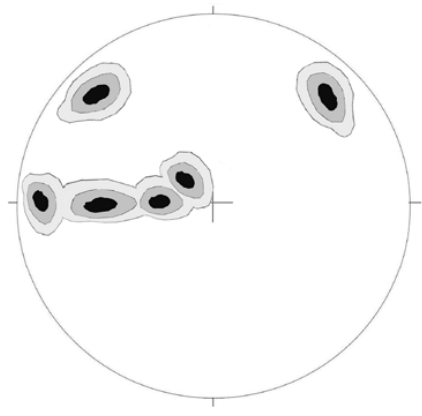

a

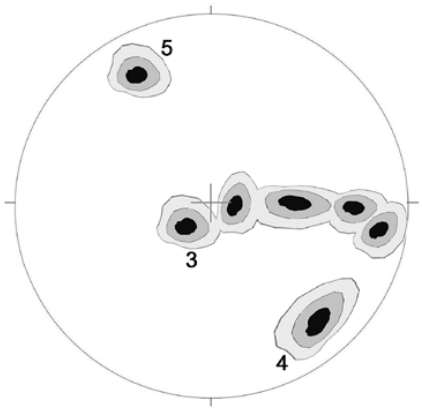

б

Рис. 3. Схематизовані стереограми полюсів площин пегматитових тіл (а) та занурення лінійності за довгими осями цих тіл

(б) для пегматитового вузла Балка Крута, за даними [3, 6, 7]. Цифри на стереограмі - інтерпретовані генерації лінійності за аналогією до подібних утворень вмісних гнейсово-сланцевих тіл

Зроблено спробу реставрувати такі перетворення у вигляді поетапної моделі еволюції структурно-речовинного малюнку фрагменту кристалічної основи, що досліджувався (рис. 4).
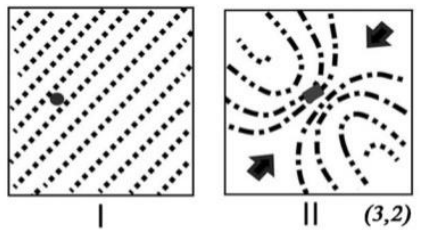

$2=:-2=$

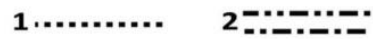

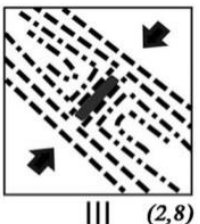

III $(2,8)$
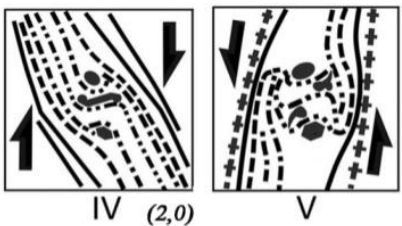

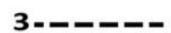

4

$5+4++4$

Рис. 4. Схематизована поетапна (I - V) модель становлення структурно-речовинного малюнку досліджуваної частини Сорокинської зони. Стрілки - реставровані напрямки прикладення тектонічних сил (в сучасних координатах). 1-5 - генерації площинних структур на відповідні етапи розвитку структурного плану. Сірі тіла (прямокутники, овали й неправильні) -

\section{рудні утворення}

3,2, 2,8, 2,0 - ізотопний вік за даними [2-4, 6]. Модель побудована відитовхуючись від здобутків попередніх дослідників [8-10 та ін.]. 


\section{Лiтература:}

1. Тектонічна карта України. Масштаб 1:1 000 000. Круглов С.С., Арсірій Ю.О., Веліканов В.Я. та ін. Мін-во охорони навколишнього природного середовища України. Державна геологічна служба. Київ: УкрДГРІ. 2007.

2. Кореляційна хроностратиграфічна схема раннього докембрію Українського щита. Єсипчук К.Ю., Бобров О.Б., Степанюк Л.М. та ін. Київ: УкрДГРІ. 2004. 28 с.

3. State geological map of Ukraine. Scale 1:200 000. Central-Ukrainian series map sheet L-37-VII (Berdyansk). Ministry of Ecology and Natural Resources of Ukraine; State geological Survey; State Enterprise «Pivdenukrgeologia» et al. Borodynya B.V., Knyazkova I.L., Esypchuk K.Yu. et al. Kyiv. 2004 (2008).

4. Геохронология раннего докембрия Украинского щита (архей). Щербак Н.П., Артеменко Г.В., Лесная И.М. и др. Киев: Наук.думка. 2005. $241 \mathrm{c}$.

5. Металогенічна карта України. М-б 1:1000 000. Гурський Д.С., Колосовська В.А., Веліканов В.А. та ін. Київ: Держгеолслужба України. 2002. 6 л.

6. Ісаков Л.В. Геолого-структурні закономірності формування полів гранітних пегматитів Східноукраїнської пегматитової області: Дис. докт. геол. наук: спец. 04.00.01 «Загальна та регіональна геологія». Дніпропетровськ. 2009. 362 с.

7. Осьмачко Л.С. Про взаємоузгодженість формування метаморфогенних комплексів Сорокинської зони, гранодіоритів Осипенківського масиву та пегматитового вузла Балка Крута (Приазовський мегаблок Українського щита). Геологічний журнал. 2020. № 4. C. 43-64.

8. Паталаха Е.И. Механизм формирования структур течения в зонах смятия. Алма-Ата: Наука. 1970. 215 с.

9. Слензак О.И. Локальные структуры зон напряжений докембрия. Киев: Наук. Думка. 1984. 102 с.

10. Passchier C. W., Trouw R. A. Microtectonics. Berlin: SpringerVerlag. 1988. 289 p. 